\title{
Suitability of Rubber Plantation Land Intercropped with Corn (Zea mays L) Plants in Betung Village of Banyuasin District
}

\author{
Kesesuaian Lahan Kebun Karet untuk Ditumpangsarikan dengan Tanaman Jagung \\ (Zea mays L) di Kelurahan Betung Banyuasin
}

\author{
Yuana Juwita $^{1 *}$, Joni Karman ${ }^{1}$, Yanter Hutapea ${ }^{1}$, Suparwoto Suparwoto ${ }^{1}$ \\ ${ }^{1}$ BPTP Balitbangtan Sumsel, South Sumatra 30151 \\ "Corresponding author: yuana_juwita@yahoo.com
}

(Received: 18 September 2019, Accepted: 24 March 2020)

Citation: Juwita Y, Karman J, Hutapea Y, Suparwoto S. 2020. Suitability of rubber plantation land intercropped with corn (Zea mays L) plants in Kelurahan Betung. Jurnal Lahan Suboptimal: Journal of Suboptimal Lands 9(1): 73-79.

\begin{abstract}
ABSTRAK
Tanaman karet merupakan salah satu komoditas unggulan perkebunan di Sumatera Selatan khususnya Kabupaten Banyuasin. Peluang lahan gawangan yang belum termanfaatkan merupakan potensi besar untuk penambahan pendapatan petani dalam budidaya tanaman. Selain karet, masyarakat Kelurahan Betung juga memelihara ternak, diantaranya yaitu sapi. Dengan demikian pemilihan tanaman jagung selain bermanfaat dalam optimalisasi gawangan karet juga menjadi salah satu sumber pakan bagi ternak. Melalui penelitian ini diharapkan dapat memberikan informasi status kesuburan tanah aktual pada daerah kajian dan melihat kesesuaian lahan tersebut bila digunakan untuk tanaman jagung, sehingga nantinya diperoleh informasi apakah lahan tersebut sesuai untuk tanaman jagung serta rekomendasi teknologi yang dibutuhkan. Hasil penelitian menunjukkan kelas kesesuaian lahan pada lokasi yaitu sesuai marjinal dengan faktor pembatas ketersediaan air (curah hujan) dan retensi hara (KB dan $\mathrm{pH})$. Untuk memperoleh hasil produksi jagung yang optimal maka disarankan perlu dilakukan pembuatan embung, serta penambahan kapur dan bahan organik.
\end{abstract}

Kata kunci: jagung, karet, kesesuaian lahan

\begin{abstract}
Rubber is one of the leading commodities of plantations in South Sumatra, especially in Banyuasin District. The opportunity for unused footpath land is a big potential in increasing farmers' income. In Betung Village, besides rubber, the community also raises livestock such as cows. This study aimed to provide information on the actual soil fertility status and see the suitability of the land in the study area when planted with corn plants, as well as the recommendations for the needed technology. The study used a survey method and the soil samples were taken using purposive random sampling method by determining the point diagonally and analyzed in the laboratory. The results of the study showed that the land suitability class at the location was according to the marginal with the limiting factors of water availability (rainfall) and nutrient retention ( $\mathrm{KB}$ and $\mathrm{pH}$ ). To obtain optimal corn production results, it is recommended to prepare a rainwater collection area and the addition of lime and organic matter.
\end{abstract}


Keywords: corn, rubber, land suitability

\section{INTRODUCTION}

Land suitability is a description of the suitability level of a piece of land for a particular use of land evaluation. According to Djaenudin et al. (2000), land evaluation is the process of estimating land suitability classes and land potential for certain land uses. In principle, land suitability assessment is carried out by matching land characteristics and land use requirements using Leibig's minimum law, i.e. plant growth is limited by minimum nutrients. In land use, evaluation of land for certain uses is an important stage. The information that will be obtained becomes the basis of management that can be used as an effort to increase production output. Banyuasin District ranks sixth in the total area of smallholder rubber plantations in South Sumatra (BPS-Badan Pusat Statistik of South Sumatra Province, 2018). According to the Agency of Statistics Center of Banyuasin District (2018), Betung Subdistrict has a total area of smallholder rubber plantations of 13,339 ha which includes 3541 ha of immature land, 7582 ha yielding land, and 2216 ha old/damaged land. In addition to the rubber plantation business, the cooperative farmer group is a member of the Community Farm School (SPR-Sekolah Peternakan Rakyat) group in which Betung Subdistrict has the largest cattle population in Banyuasin District. Corn is one of the strategic commodities in agricultural development because it cannot only be used as a food source but also used as a source of animal feed. However, the corn harvest area in Betung Subdistrict in 2017 was 10 hectares, $0.04 \%$ of the total district corn harvest area of 20,510 ha.

The expansion of planting areas and the use of superior seeds in corn cultivation are efforts taken to increase production. At the study site, most of the cultivated rubber plantations use monoculture planting patterns and many do not apply intercropping systems. The opportunity of unused footpath land is a great potential for additional income so that it is appropriate for the expansion of corn planting to increase production through the intercropping system in rubber plantations. The selection of corn is considered appropriate because apart from being an intercropping plant it is also useful as a source of cattle feed.

The rubber plants chosen to be intercropped with corn plants are those of two years old because an old rubber plantation with a wider canopy area can affect the light intensity received by the corn plants. According to Yulius et al. (2013), the low light intensity obtained by corn plants as rubber interrupted plants affects the number of leaves and the length of corncobs since it is influenced by the rate of nutrient absorption which is lower in shaded corn. In rubber and corn intercropping, not only can the corn fruit be benefited, but also the leaves or the stovers can be used as alternative fodder by the local community. The results of Ardi and Firdaus's research (2007) shows that planting corns as intermittent plants in rubber plants can have a positive influence on rubber plants as well as on crops of the intermittent plants. The intercrops planted between rubber plants have a positive effect on the growth of rubber stem twists and are better than monoculture rubber plantations because the intercropping plant maintenance activities result in a positive contribution to rubber plants (Rosyid et al., 2004). This study aimed to evaluate the land suitability for corn planting and find out information on follow-up efforts that need to be conducted.

\section{MATERIALS AND METHODS}

The material used in this study was a sample of soil representing research sites and chemicals for soil analysis in the Laboratory. The research method used was a survey method evaluating qualitative land 
suitability by comparing land characteristics and quality data in the field with land suitability criteria according to Djaenudin et al. (2000) so that land suitability classes and their limiting factors were obtained. The results of this information were expected that problem solvers were obtained from the limiting factors so as to increase the crop production and land productivity. The research was carried out starting from the determination of the activity location to the soil analysis, from January to May 2018. The location was in the Beringin Jaya farmer group, Betung Village of Betung Subdistrict, Banyuasin District. The soil samples were taken using purposive random sampling method by determining the point diagonally. The soil was taken as many as 6 samples, the depth of approximately $30 \mathrm{~cm}$ which was not intact. The samples were then analyzed for their soil chemical at the Sembawa Research Center of Rubber Laboratory, Banyuasin. The soil physical properties were analyzed for their soil texture (Hydrometer Method), while their chemical properties included C-organic (Welkey and Black Method), CEC or cation exchanging capacity and exchangeable base-base exchange ( $\mathrm{Ca}, \mathrm{Mg}, \mathrm{Na}$, and $\mathrm{K}$ ) $\mathrm{NH}_{4} \mathrm{C}_{2} \mathrm{H}_{3} \mathrm{O}_{2} \mathrm{pH} 7$ Method, and $\mathrm{pH} \mathrm{H}_{2} \mathrm{O}$ Electrometric Method. In addition to taking soil samples, soil observations and physical observations of the area environment were carried out according to the information of needs of land use or land characteristics according to Djaenudin et al. (2000).

\section{RESULTS AND DISCUSSION}

\section{Description of Research Locations}

The research location was in Betung Village of the Beringin Jaya Farmers Group land. Administratively, Betung Village is one of the eleven vilages located in Betung Subdistrict of Banyuasin District, South Sumatra Province. Land typology of Betung District is mostly dry land with a rather bumpy topography and partly tidal swamp land. There are four types of soil in
Banyuasin District; Organosols, Klei or humus in lowlands/swamps, Alluvial along rivers, and Podzolik in hilly areas. (BPS of Banyuasin District, 2018). The main source of income of the population and types of main agricultural commodities based on the villages of Betung Subdistrict is agriculture with the main type of agricultural commodity of rubber (BPS of Betung Subdistrict, 2018). While in the production of food commodities (Pajale) which is currently promoted by the government, corn is the second largest commodity produced after rice. In addition to the cultivation business, the Betung Village community also manages and develops livestock such as cattle. Smallholder rubber plantations where the land evaluation was carried out belong to immature rubber plantations. The age of the rubber plants was below 2 years having planting distance of $5 \times 3.5 \mathrm{~m}$.

\section{Physical Environment and Land Suitability Class}

The interview results with the farmers in the study location showed that the corn planting area was never flooded. In observation of the rocks on the surface and outcrops of rocks, the results showed that they were less than 5\%. Drainage is the rate of water percolation going into the ground against the aerated air in the soil. Based on the field observations, the drainage class was deep, rather fast, having the soil color without homogeneity, spotting, or iron rust. The land characteristic for toxicity is soil salinity and according to Darmawijaya (1992) salinization only occurs in river deltas affected by sea water or the coast so as to see the condition of the location far from the coast, it is assumed that the salinity value is 0 or less than $1.1 \mathrm{~s} / \mathrm{m}$. The sulfidic depth in the study area was also not measured because the location was not affected by the tides so it was assumed to be more than $125 \mathrm{~cm}$. Based on the results of the observations and analysis of the land characteristics from the location of the activity (Table 1), the land suitability 
classes of the research location for corn (rainfall) and nutrient retention (KB and plants were marginal according to the $\mathrm{pH}$ ).

limiting factors of water availability

Table 1. Requirements for land characteristics and matching results of land suitability classes

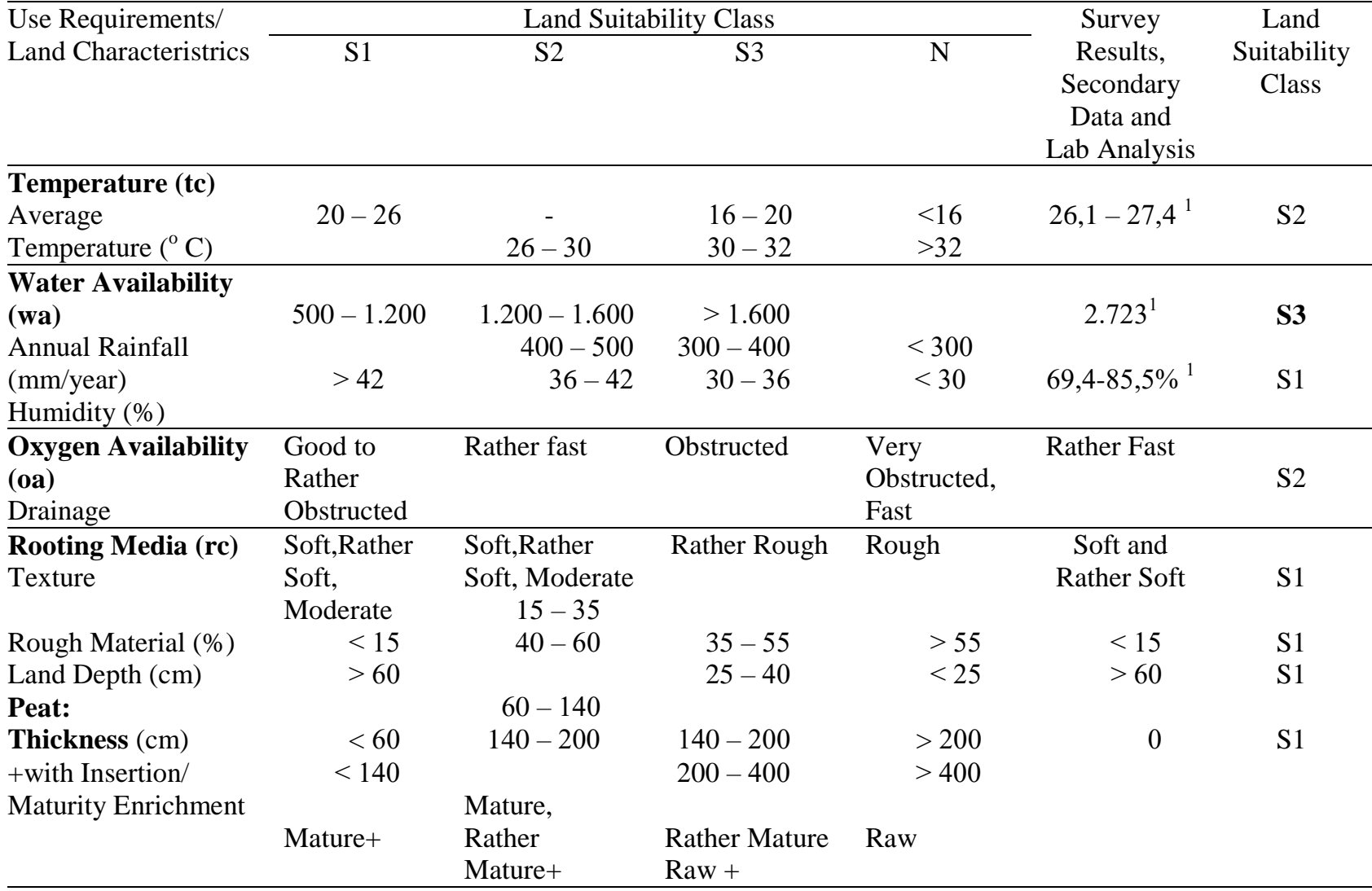

Nutrient Retention

(nr)

CEC Clay

$(\mathrm{Cmol} / \mathrm{Kg})$

Base Saturation $(\%)$

$\mathrm{pH} \mathrm{H}_{2} \mathrm{O}$

$\begin{array}{rrr}>16 & \leq 16 & \\ >50 & 35-50 & <35 \\ 5,8-7,8 & 5,5-5,8 & <5,5 \\ & 7,8-8,2 & >8,2 \\ >0,4 & <0,4 & \end{array}$

$<5,5$

8,2
9,19

12

4,4

S1

S3

S3

2,12

S1

C-Organic (\%)

\begin{tabular}{|c|c|c|c|c|c|c|}
\hline $\begin{array}{l}\text { Toxicity (xc) } \\
\text { Salinity }(\mathrm{dS} / \mathrm{m})\end{array}$ & $<4$ & $4-6$ & $6-8$ & $>8$ & $1,12-1,28$ & $\mathrm{~S} 1$ \\
\hline Sodicity (xn) & & & & & & \\
\hline Alkalinity/ESP (\%) & $<15$ & $15-20$ & $20-25$ & $>25$ & $<15$ & $\mathrm{~S} 1$ \\
\hline $\begin{array}{l}\text { Sulfidic Hazards } \\
(\mathrm{xs}) \\
\text { Sulfidic Depth }(\mathrm{cm})\end{array}$ & $>100$ & $75-100$ & $40-75$ & $<40$ & $>100$ & $\mathrm{~S} 1$ \\
\hline $\begin{array}{l}\text { Erosion Hazard } \\
\text { (eh) } \\
\text { Slope }(\%) \\
\text { Erosion Hazard }\end{array}$ & $\begin{array}{c}\quad<8 \\
\text { Very Light }\end{array}$ & $\begin{array}{l}\quad 8-16 \\
\text { Light - } \\
\text { Moderate }\end{array}$ & $\begin{array}{l}16-30 \\
\text { Heavy }\end{array}$ & $\begin{array}{c}>30 \\
\text { Very Heavy }\end{array}$ & $\begin{array}{c}<8 \\
\text { Very Light }\end{array}$ & $\begin{array}{l}\text { S1 } \\
\text { S1 }\end{array}$ \\
\hline $\begin{array}{l}\text { Flood Hazard (fh) } \\
\text { Puddle }\end{array}$ & F0 & - & $\mathrm{F} 1$ & $>\mathrm{F} 2$ & F0 & $\mathrm{S} 1$ \\
\hline $\begin{array}{l}\text { Land Preparation } \\
\text { (lp) } \\
\text { Rock on the Surface } \\
(\%) \\
\text { Rock Outcrops }(\%)\end{array}$ & $\begin{array}{l}<5 \\
<5\end{array}$ & $\begin{array}{l}5-15 \\
5-15\end{array}$ & $\begin{array}{l}15-40 \\
15-25\end{array}$ & $\begin{array}{l}>40 \\
>25\end{array}$ & $\begin{array}{l}<5 \\
<5\end{array}$ & $\begin{array}{l}\text { S1 } \\
\text { S1 }\end{array}$ \\
\hline
\end{tabular}

Notes: ${ }^{1}=$ Pusdatin, (2017) 
The evaluation results showed that the obtained suitability classes of land in rubber plantations for intercropping with corn plants at the location of the activity was marginal according to the factors limiting water availability and nutrient retention (S3wa, nr).

The first characteristic limiting the water availability was annual rainfall. The rainfall of the study site was $2,723 \mathrm{~mm}$ per year (Data and Information Center, 2017). According to Akil and Dahlan (2007) in limited rainfall areas, the planting of corn cannot be delayed because the plants have the potential to suffer from drought or crop failure. The results of the study conducted by Wirosoedarmono et al. (2011) suggested that corn plants needed a lot of water when flowering, but the short rainy season with sunshine is much better than continuous rain. The existence of high rainfall can cause soil stability to decline and the organic matter and nutrients in the soil can be dissolved.

The rainfall limiting factor according to Ritung et al. (2011) can still be improved. At the moderate level of processing the land quality can be improved to one higher level (S3 to S2), even if there is a high level of processing the grade can increase to two levels higher (S3 to $\mathrm{S} 1$ ), and processing activities can be carried out with irrigation. According to Rusli and Heryana (2015), irrigation on rubber land is only carried out on nurseries on a non-extensive scale, the availability of water sources being a limiting factor for irrigation applications on $\mathrm{TBM}$ and TM rubber plants. In line with the conditions in the field, due to limited water sources, other alternatives are needed that can be done for example by making a water reservoir.

Embung (rainwater collection) is a water conservation building in the form of a pond to collect rainwater and runoff water as well as from other water sources that are usually built in areas outside the river. According to Fath (2017) in making reservoirs, good planning is needed and the planning comes from the fields of science, among others, geology, hydrology, hydraulics and soil mechanics. After making the water conservation building, the thing that needs to be considered for the sustainability of the function of the reservoir is maintenance. Beside as a rainwater collection, the water in this reservoir can later be used when the dry season arrives.

Besides the rainfall, another characteristic limiting the development of corn plants at the study location was nutrient susceptibility, namely base saturation and $\mathrm{pH}$. Base saturation is the total percentage of cation exchange capacity (CEC) occupied by base cations such as potassium, calcium, magnesium, and sodium. While the $\mathrm{pH}$ is the amount of $[\mathrm{H}+]$ dissolved in the soil, the higher the $[\mathrm{H}+]$, the $\mathrm{pH}$ value will be more acidic, otherwise the lower it will be more alkaline.

According to Ritung et al. (2011), having this limitation, the efforts to improve land quality can be done by liming and adding organic material. Moderate and low levels of processing land suitability will increase one or two levels above it.

The organic matter in the soil has an important role, namely its ability to react with metal ions to form complex compounds, so that the metal ions (Al, Fe, and $\mathrm{Mn}$ ) that have the potential to poison plants can be reduced by the presence of bonds with these organic materials (Setyorini et al., 2006). The decrease of the content of organic matter in the soil can occur because of intensive soil process without returning the organic matter. (Rachman, 2017).

Organic materials can be added from compost, green manure, agricultural waste and livestock manure. Adding organic materials at the location of the activity should utilize the available organic material sources. The source of organic material that has the potential to be reused in the study location is cattle waste, both in the form of cow dung and urine. Besides growing green manure or legume plants around the land, according to Simanungkalit (2006) the source of organic material can be an 
alternative since it is a cheap source of organic material. The application of manure and green manure can reduce the dose of inorganic fertilizer without reducing the yield of corn plant production (Magdalena et al., 2013).

Land preparation is very dependent on the physical soil such as soil texture. Heavy textured soils need intensive tillage, on the contrary light to medium textured soils such as at the study location can be prepared with conservation tillage techniques, namely with minimum tillage or without tillage (Akil and Dahlan, 2007).

Based on the study results of Fitriyah et al. (2016) tillage system significantly affected the abundance of nematodes in the soil. Compared to an intensive tillage treatment, the minimum tillage treatment can increase the abundance of all nematodes in the study results. The minimum tillage also influences nutrient uptake, minimum tillage plus herbicide significantly produces the highest total $\mathrm{N}, \mathrm{P}$ and $\mathrm{K}$ nutrient uptake and produces the highest economic value compared to the minimum tillage treatment, perfect tillage, and perfect tillage plus herbicide (Oktaviansyah et al., 2015).

\section{CONCLUSION}

The suitability class of rubber plantation land at the study location for corn plants is marginal (S3) with limiting factors in water availability (rainfall) and nutrient retention (KB and $\mathrm{pH}$ ). To make the land feasible for planting corn, the efforts that must be made are: the supply of water sources such as reservoirs, addition of lime and the addition of organic material. Addition of organic material can be done by utilizing livestock waste (cow manure and urine), and planting green manure or legume plants around the land.

\section{REFERENCES}

Ardi, Firdaus. 2007. Analisis finansial tumpangsari jagung pada perkebunan karet rakyat. balai pengkajian teknologi pertanian. $20 \mathrm{hlm}$.

Akil M, Dahlan HA. 2007. Budidaya jagung dan diseminasi teknologi. jagung: teknik produksi dan pengembangan. Pusat Penelitian dan Pengembangan Tanaman Pangan, Bogor. pp:192-204.

Badan Pusat Statistik Provinsi Sumsel. 2018. Provinsi Sumatera Selatan Dalam Angka. BPS Provinsi Sumsel, Palembang. $258 \mathrm{hlm}$.

Badan Pusat Statistik Kabupaten Banyuasin. 2018. Kabupaten Banyuasin Dalam Angka. BPS Kabupaten Banyuasin, Banyuasin. 338 hlm.

Badan Pusat Statistik Kecamatan Betung. 2018. Kecamatan Betung Dalam Angka. BPS Kabupaten Banyuasin, Banyuasin. $50 \mathrm{hlm}$.

Djaenudin, Marwan H, Subagyo H, Mulyani A, Suharta N. 2000. Kriteria kesesuain lahan untuk komoditas pertanian. pusat penelitian tanah dan agroklimat, badan penelitian dan pengembangan pertanian. $264 \mathrm{hlm}$.

Darmawijaya I. 1992. Buku klasifikasi tanah, dasar teori bagi peneliti tanah dan pelaksana pertanian di Indonesia. Gadjah Mada University Press. Bulaksumur Yogyakarta. $411 \mathrm{hlm}$.

Fath ZKN. 2017. Perencanaan Embung di PT Perkebunan Nusantara 7 unit usaha bunga mayang kabupaten Lampung Utara. Fakultas Teknik, Universitas Lampung, Bandar Lampung. $91 \mathrm{hlm}$.

Fitriyah WM, I Gede Swibawa, Solikhin. 2016. Pengaruh sistem olah tanah dan pengelolaan gulma terhadap kelompok makan komunitas nematoda tanah pada pertanaman jagung (Zea mays L.) di laboratorium lapangan terpadu Fakultas Pertanian Universitas Lampung. Agrotek Tropika. 4(2): 146-150.

Magdalena F, Sudiarso, Sumarni T. 2013. Penggunaan pupuk kandang dan pupuk hijau Crotalaria Juncea L. untuk mengurangi penggunaan pupuk anorganik pada tanaman jagung (Zea mays. L). Jurnal Produksi Tanaman. 1(2): 61-71. 
Oktaviansyah H, Jamalam Lumbanraja, Sunyoto dan Sarno. 2015. Pengaruh sistem olah tanah terhadap pertumbuhan, serapan hara dan produksi tanaman jagung pada tanah ultisol gedung meneng Bandar Lampung. Agrotek Tropika. 3(3):393-401.

Data and Information Center. 2017. Bumdesa dan Bumndesa Bersama di Kawasan Transmigrasi Telang, Kabupaten Banyuasin Provinsi Sumatera Selatan. Badan Penelitian dan Pengembangan, Pendidikan dan Pelatihan, dan Informasi Kementerian Desa, Pembangunan Daerah Tertinggal dan Transmigrasi, Jakarta. 73 hal.

Rachman A. 2017. Peluang dan tantangan implementasi model pertanian konservasi di lahan kering. Sumber Daya Lahan. 11 (2): 77-90.

Rosyid MJ, Supriadi M, Nancy C. 2004. Analisis Kelayakan Lahan di Desa-Desa Peserta Proyek Peremajaan Karet Partisipatif di kabupaten Musi Banyuasin, Sumatera Selatan. Warta Perkaretan. 2 (1): 73-83.

Ritung S, Nugroho K, Mulyani A, Suryani. E. 2011. Petunjuk teknis evaluasi lahan untuk komoditas pertanian (Edisi Revisi). Balai Besar Penelitian dan Pengembangan Sumberdaya Lahan Pertanian, Badan Penelitian dan Pengembangan Pertanian, Bogor. 168 hlm.

Rusli, Heryana N. 2015. Dampak dan Antisipasi Kekeringan Pada Tanaman Karet. Jurnal Sirinov. 3(2): 83-92.

Setyorini D, Saraswati R, Anwar EK. 2006. Kompos. buku pupuk organik dan pupuk hayati. balai besar litbang sumber daya lahan pertanian. pp. 11-40.

Simanungkalit RDM. 2006. Prospek pupuk organik dan pupuk hayati di indonesia. buku pupuk organik dan pupuk hayati. balai besar litbang sumber daya lahan pertanian. pp. 265-271.

Yulius F, Dibyo Pranowo, Rusli. 2013. Pengaruh tanaman sela terhadap pertumbuhan tanaman karet muda pada sistem penembangan bertahap. Buletin Ristri, 4(3): 225-230.

Wirosoedarmono R, Sutanhaji AT, Kurniati E, Wijayant R. 2011. Evaluasi Kesesuaian Lahan Untuk Tanaman Jagung Menggunakan Metode Analisis Spasial. Agritech. 31(1): 71-78. 